\title{
NEW TREE SPECIES FROM ESMERALDAS, ECUADOR
}

\author{
ELBERT L. LITTLE, JR.
}

Some undescribed tree species were collected in 1965-1966 by the forest survey in the wet tropical (rain) forests of the Province of Esmeraldas along the Pacific coast in northwestem Ecuador. Five new species are published here in the following genera (and families): Coussapoa (Moraceae), Magnolia (Magnoliaceae), Matisia (Bombacaceae), Rudgea (Rubiaceae), and Sickingia (Rubiaceae). Each description is accompanied by a line drawing prepared for a book on the common trees of Esmeraldas now awaiting publication. Descriptions of the new species will be continued in later numbers of Phytologia.

In March-July 1943 I made a collection of tree specimens in western Ecuador as dendrologist with the forest survey by the Latin American Forest Resources Project, of the Forest Service, United States Department of Agriculture. This was a World War II project in cooperation with the Office of the Coordinator of Inter-American Affairs. Further information about the important trees is contai ned in the published report: Holdridge, L. R., et al. The forests of western and central Ecuador. 134 pp., illus. Forest Service, U. S. Dept. Agr. 1947.

Various.new tree species were named from that collection. I published 19, including 12 from Esmeraldas (New species of trees from western Ecuador. Wash. Acad. Sci. Jour. 38: 87-105, illus. 1348), also a list of the identifications with notes (A collection of tree specimens from western Ecuador. Caribbean Forester 9: 215-298. 1948).

A 5-year forestry project, including an inventory and entitled Desarrollo Forestal de Noroccidente (DEFOPNO), was begun in Esmeraldas in 1964. This was United Nations Special Fund Project No. 127, administered by the Food and Agriculture Organization (FAO) of the United Nations and the Government of Ecuador. I served as consultant on this project, making a brief trip to Ecuador in February 1965 and another for two months field work in Esmeraldas in September-October 1965. Robért G. Dixon, silviculturist on the project, and I collected about 250 numbers of herbarium specimens of trees, many with wood samples for testing. About 100 additional numbers were collected by others. After my return to Washington, D. C., I identified the specimens at the U. S. National Herbarium, United States National Museum, with the assistance of specialists. Also, I prepared botanical descriptions for the forthcoming book. This work was financed by the project through Special Service Agreements. 
$A$ set of the herbarium specimens including holotypes of the new species described here is being deposited in the U. S. National Museum (US). A duplicate set is being retained by the forestry project in Quito, Ecuador. Isotypes will be deposited in the herbarium of the New York Botanical Garden (NY). Wood samples are being placed in the Wood Collection, U. S. Forest Products Laboratory, Madison, Wisconsin (MADw).

The assistance of Elbert S. Reid, director, Robert G. Dixon, silviculturist, and others of the project in many ways is gratefully acknowledged. Credit is due several artists for the fullpage line drawings of the new species prepared for the book and reproduced here first. Most drawings of the new species are by Anita Ortiz, Jaime F. Cárdenas, and Antonio Dueñas V. Two are by Carol Ann Kanter.

COUSSAPOA ROTUNDA Little, sp. nov. "Matapalo." Fig. 1.

Arbor epiphytica vel scandens ad $15 \mathrm{~m}$. alta, trunco $15 \mathrm{~cm}$. diametro. Cortex griseus laevis vel parum fissuratus. Ramuli crassi pubescentes, cicatricibus obliquis stipularum notati. Stipulae 1-3 cm. longae, acuminatae puberulae gemmam anguste oblongam formantes, caducae. Foliorum alternorum petioli 1-2.5 $\mathrm{cm}$. longi, crassi pubescentes, longitudinaliter sulcati. Laminae rotundae, 6-15 cm. longae et latae, apice rotundatae, basi cordatae vel rotundatae, margine leviter undulatae, coriaceae, supra glabrae virides, subtus flavo-virides, venatione palmata nervis principalibus 9 vel 7 , supra valde impressis, subtus puberulis, venulis numerosis parallelis.

Inflorescentiae masculinae pedunculis $1-2.5 \mathrm{~cm}$. Iongis pubescentibus, 2-4-plo dichotome ramosae, capitula numerosa globosa 3-l $\mathrm{mm}$. diametro pedicellis puberulis $1-3 \mathrm{~mm}$. longis ferentes. Flores masculini numerosi sessiles sepalis 3 pubescentibus 0.5 $\mathrm{mm}$. longis stamine unico $1 \mathrm{~mm}$. longo. Flores feminei fructique non visi.

Epiphytic tree or vine to $15 \mathrm{~m}$. high, with trunk $15 \mathrm{~cm}$. in diameter. Bark gray, smooth or slightly fissured. Twigs stout, pubescent, with oblique stipule scars. Stipules $1-3 \mathrm{~cm}$. long, acuminate, puberulent, forming narrowly oblong bud, caducous. Petioles of the alternate leaves $1-2.5 \mathrm{~cm}$. long, stout, pubescent, longitudinally grooved. Blades round, $6-15 \mathrm{~cm}$. long and broad, rounded at apex, cordate or rounded at base, with margin slightly wavy, coriaceous, above glabrous and green, beneath yellow green, palmately veined with 9 or 7 principal veins very impressed and puberulent beneath, and with numerous parallel veinlets.

Male inflorescences with pubescent peduncles $1-2.5 \mathrm{~cm}$. long, 2-4 times dichotomous, bearing numerous globose heads $3-4 \mathrm{~mm}$. in diameter on puberulent pedicels $1-3 \mathrm{~mm}$. long. Male flowers numerous, sessile, with 3 pubescent sepals $0.5 \mathrm{~mm}$. Iong and 1 stamen $1 \mathrm{~mm}$. long. Female flowers and fruits not seen. 


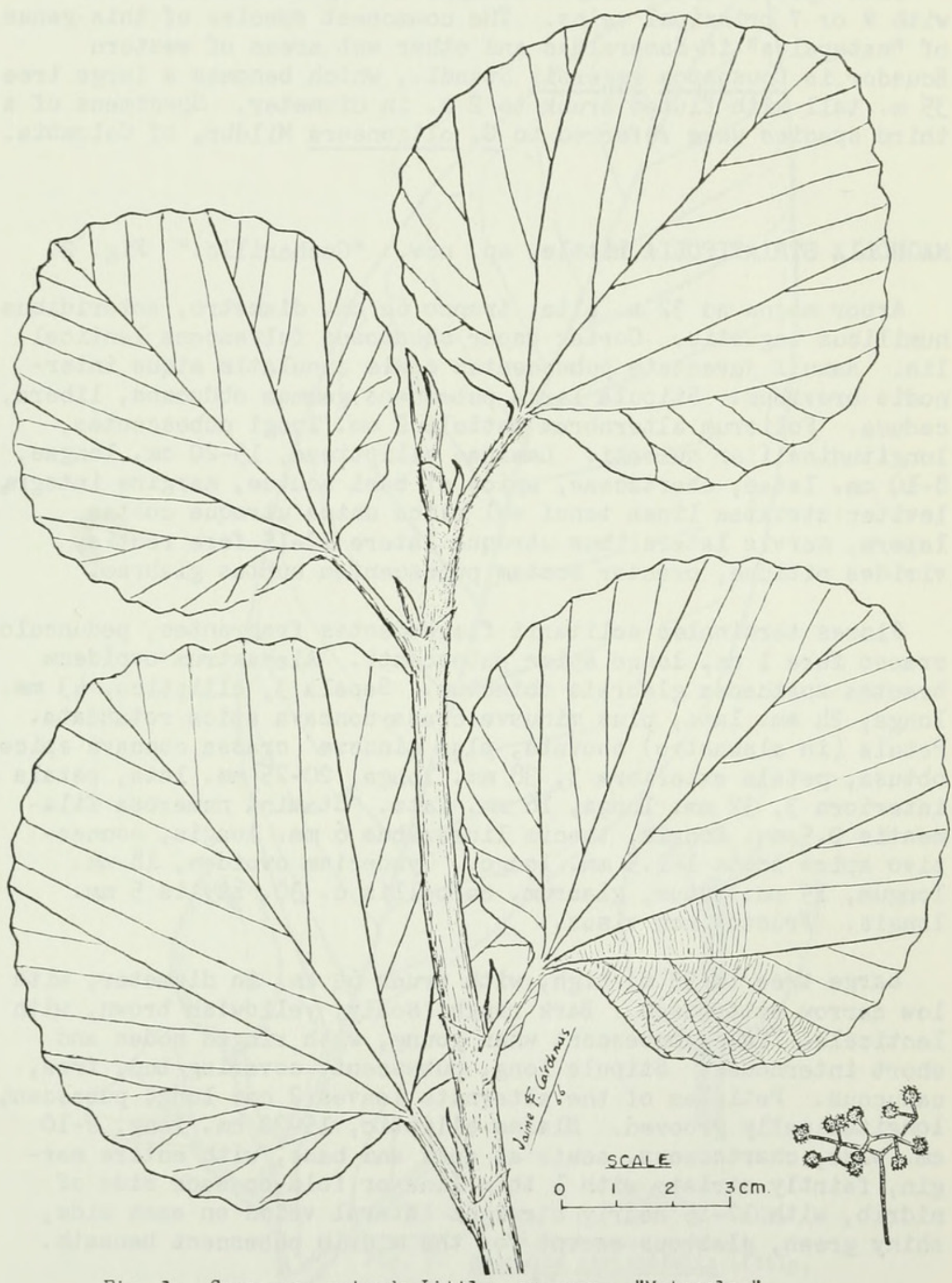

Fig. 1. Coussapoa rotunda Little, sp. nov. "Matapalo." 
ECUADOR, ESMERALDAS: Junction of Río Hoja Blanca and Río Hualpi, $50 \mathrm{~km}$. S. of Borbón, alt. $75 \mathrm{~m}$., wet tropical forest, Sept. I4, 1965, E. L. Little, Jr.2 and R. G. Dixon 21056 (HOLOTYPE, US; isotype, NY).

This species is readily distinguished by its rounded leaves with 9 or 7 principal veins. The commonest species of this genus of "matapalos" in Esmeraldas and other wet areas of western Ecuador is Coussapoa eggersii Standl., which becomes a large tree $35 \mathrm{~m}$. tall with fluted trunk to $2 \mathrm{~m}$. in diameter. Specimens of a third species were referred to $\underline{C}$. oligoneura Mildbr, of Colombia.

MAGNOLIA STRIATIFOLIA Little, sp. nov. "Cucharillo." Fig. 2.

Arbor magna ad $32 \mathrm{~m}$. alta, trunco $64 \mathrm{~cm}$. diametro, anteridibus humilibus angustis. Cortex asper squamosus fulvescens lenticellis. Ramuli juventute pubescentes nodis annulatis atque internodis brevibus. Stipula larga pubescens gemmam obducens, libera, caduca. Foliorum alternorum petioli $2 \mathrm{~cm}$. longi pubescentes, longitudinaliter sulcati. Laminae ellipticae, $15-20 \mathrm{~cm}$. Iongae, 8-10 cm. latae, chartaceae, apice et basi acutae, margine integra, leviter striatae linea tenui vel plica unica utroque costae latere, nervis lateralibus utroque latere $12-15$ fere rectis, virides nitidae, praeter costam pubescentem subtus glabrae.

Flores terminales solitarii flavescentes fragrantes, pedunculo crasso fere $1 \mathrm{~cm}$. longo apice pubescenti. Alabastrum ovoideum bractea spathacea glabrata obtectum. Sepala 3, elliptica, $43 \mathrm{~mm}$. longa, $24 \mathrm{~mm}$. lata, plus minusve crassaconcava apice rotundata. Petala (in alabastro) obovata, plus minusve crassa concava apice obtusa, petala exteriora $3,38 \mathrm{~mm}$. Ionga, 20-25 mm. lata, petala interiora 3, $32 \mathrm{~mm}$. longa, $16 \mathrm{~mm}$. lata. Stamina numerosa filamentis $0.5 \mathrm{~mm}$. longis, thecis linearibus $6 \mathrm{~mm}$. longis, connectivo apice acuto $1-1.5 \mathrm{~mm}$. longo. Gynoecium ovoidem, $18 \mathrm{~mm}$. longum, $15 \mathrm{~mm}$. latum, glabrum, carpellis c. 30 , stylis $5 \mathrm{~mm}$. longis. Fructus non visus.

Large tree to $32 \mathrm{~m}$. high, with trunk $64 \mathrm{~cm}$. in diameter, with low narrow buttresses. Bark rough, scaly, yellowish brown, with lenticels. Twigs pubescent when young, with ringed nodes and short intermodes. Stipule long, pubescent, covering bud, free, caducous. Petioles of the alternate leaves $2 \mathrm{~cm}$. long, pubescent, longitudinally grooved. Blades elliptic, $15-20 \mathrm{~cm}$. long, 8-10 $\mathrm{cm}$. wide, chartaceous, acute at apex and base, with entire margin, faintly striate with 1 thin line or fold on each side of midrib, with 12-15 nearly straight lateral veins on each side, shiny green, glabrous except for the midrib pubescent beneath. 


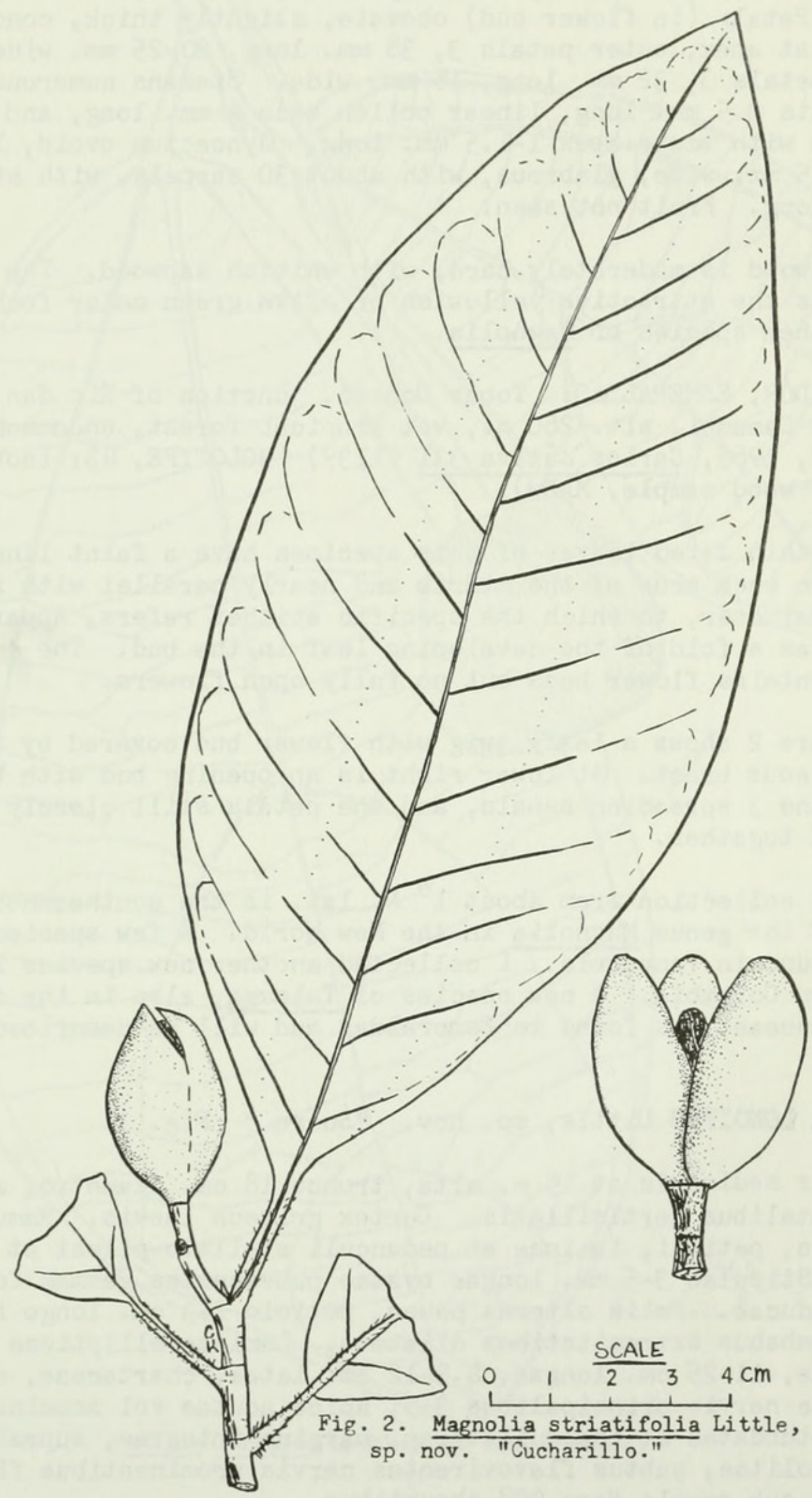


Flowers terminal, solitary, yellowish, fragrant, with stout peduncle nearly $1 \mathrm{~cm}$. long pubescent at apex. Flower bud ovoid, covered by a glabrate spathaceous bract. Sepals 3, elliptic, $43 \mathrm{~mm}$. long, $24 \mathrm{~mm}$. wide, slightly thick, concave, rounded at apex. Petals (in flower bud) obovate, slightly thick, concave, obtuse at apex, outer petals $3,38 \mathrm{~mm}$. long, $20-25 \mathrm{~mm}$. wide, inner petals $3,32 \mathrm{~mm}$. long, $16 \mathrm{~mm}$. wide. Stamens numerous with filaments $0.5 \mathrm{~mm}$. long, linear pollen sacs $6 \mathrm{~mm}$. long, and connective with acute apex 1-1.5 mm. long. Gynoecium ovoid, $18 \mathrm{~mm}$. long, $15 \mathrm{~mm}$. wide, glabrous, with about 30 carpels, with styles $5 \mathrm{~mm}$. long. Fruit not seen.

The wood is moderately hard, with whitish sapwood. The heartwood has the attractive yellowish or olive green color found in some other species of Magnolia.

ECUADOR, ESMERALDAS: Tobar Donoso, junction of Río San Juan and Río Camumbi, alt. $260 \mathrm{~m}$., wet tropical forest, uncommon, July 27, 1966, Carlos Játiva 331 (1139) (HOLOTYPE, US; isotypes, LA, NY; wood sample, MADw).

The thin dried leaves of this specimen have a faint line or stria on each side of the midrib and nearly parallel with it. This character, to which the specific eoithet refers, apparently indicates a fold of the developing leaf in the bud. The collection contains flower buds but no fully open flowers.

Figure 2 shows a leafy twig with flower bud covered by the spathaceous bract. At lower right is an opening bud with bract shed, the 3 spreading sepals, and the petals still closely pressed together.

This collection from about $1^{\circ} \mathrm{N}$. lat. is the southernmost record of the genus Magnolia in the New World. A few species have been found in Venezuela. I collected another new species in southern Colombia. A new species of Talauma, also in the family Magnoliaceae, was found in Esmeraldas and will be described.

MATISIA LONGIPES Little, sp. nov. "Suare." Fig. 3.

Arbor mediocris at $15 \mathrm{~m}$. alta, trunco $18 \mathrm{~cm}$. diametro, ramis horizontalibus verticillatis. Cortex griseus laevis. Ramuli graciles, petioli, laminae et pedunculi stellato-pilosi et lepidoti. Stipulae $3-5 \mathrm{~mm}$. Iongae ovatae pubescentes gemmam formantes, caducae. Folia alterna pauca, petiolo 2-3 cm. longo fulvescenti ambabus extremitatibus dilatato. Laminae ellipticae vel obovatae, $11-25 \mathrm{~cm}$. longae, $4 \cdot 5-12 \mathrm{~cm}$. latae, chartaceae, asymmetricae nervis principalibus $3-5$, apice acutae vel acuminatae, basi rotundatae et inaequilaterae, margine integrae, supra virides impolitae, subtus flavovirentes nervis prominentibus flavidis, venulis sub angulo fere $90^{\circ}$ abeuntibus. 


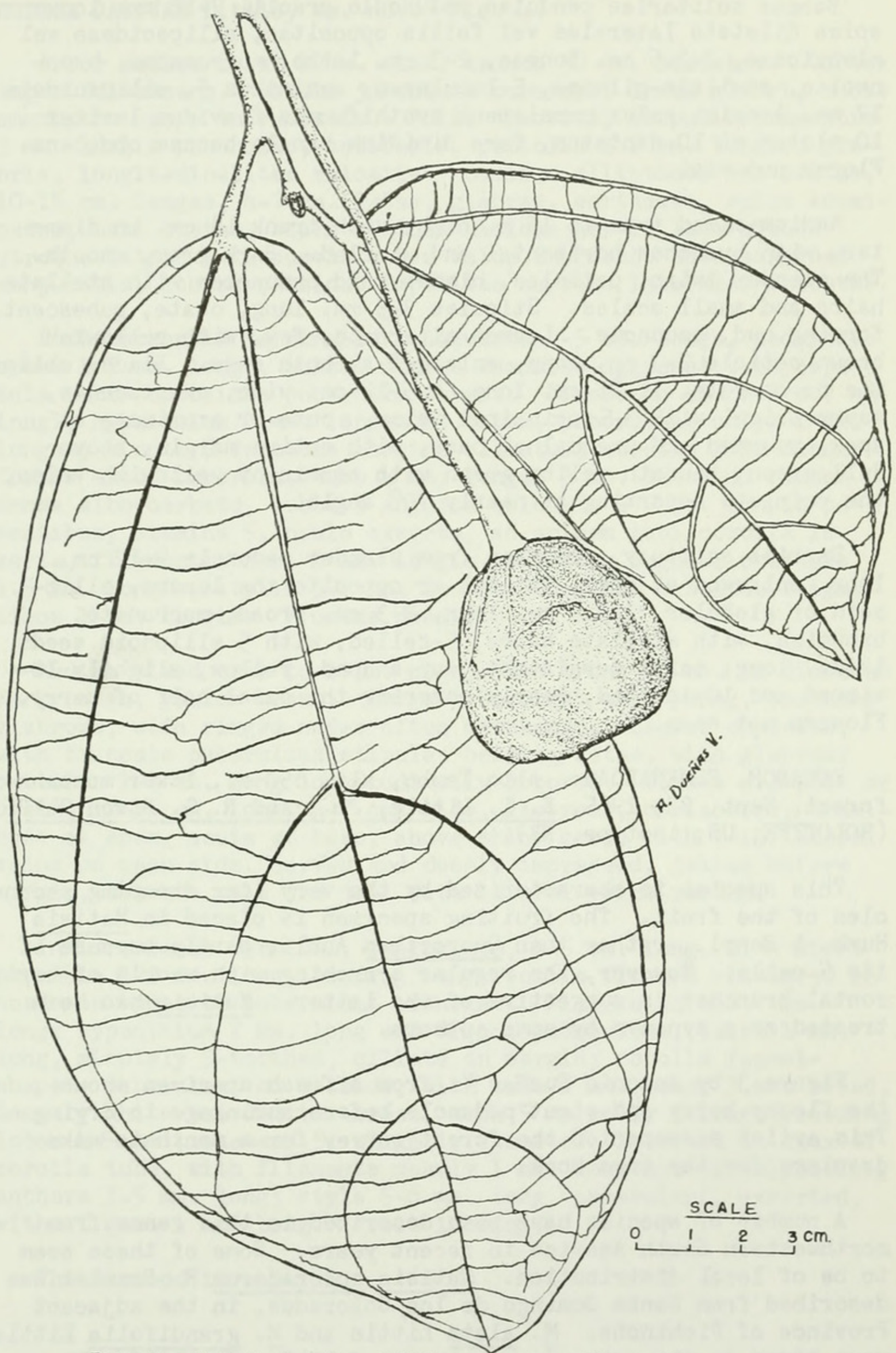

Fig. 3. Matisia longipes Little, sp. nov. "Suare." 
Baccae solitariae pendulae pedunculo gracili $7-12 \mathrm{~cm}$. longo apice dilatato laterales vel foli1s oppositae, ellipsoideae vel globulosae, $3-3.5 \mathrm{~cm}$. longae, $2-3 \mathrm{~cm}$. 1 atae, mucronatae, brunneolae, stellato-pilosae, 5-loculares, seminibus 5, ellípsoideis $17 \mathrm{~mm}$. long1s; calyx persistens cyathiformis flavidus leviter 10-alatus et 10-dentatus, fere dimidium basale baccae obducens. Flores non visi.

Medium-sized tree to $15 \mathrm{~m}$. high, with trunk $18 \mathrm{~cm}$. in diameter, with branches horizontal and whorled. Bark gray, smooth. The slender twigs, petioles, blades, and peduncles with stellate hairs and small scales. Stipules 3-5 mm. long, ovate, pubescent, forming bud, caducous. Leaves alternate, few, with yellowish brown petiole $2-3 \mathrm{~cm}$. long, enlarged at both ends. Blades elliptic or obovate, 11-25 cm. long, $4.5-12 \mathrm{~cm}$. wide, chartaceous, asymmetrical with $3-5$ principal veins, acute or acuminate at apex, rounded and urequal at base, with entire margin, above dull green, beneath yellow green with prominent yellowish veins, the veinlets departing at nearly $90^{\circ}$ angle.

Berries solitary, drooping from slender peduncle $9-12 \mathrm{~cm}$. long enlarged at apex, lateral or opposite the leaves, ellipsoid or globular, $3-3.5 \mathrm{~cm}$. long, $2-3 \mathrm{~cm}$. broad, mucronate, brownish, with stellate hairs, 5-celled, with 5 ellipsoid seeds $17 \mathrm{~mm}$. long; calyx persistent, cup-shaped, yellow, slightly 10winged and 10-toothed, nearly covering the basal half of berry. Flowers not seen.

ECUADOR, ESMERALDAS: Alto Tambo, alt. $650 \mathrm{~m}$., lower montane forest, Sept. 23, 1965, E. L. Little, Jr., and R. G. Dixon 21125 (HOLOTYPE, US; isotype, $\overline{\mathrm{NY}}$ ).

This species is characterized by the very long drooping peduncles of the fruit. The fruiting specimen is placed in Matisia Humb. \& Bonpl., rather than Quararibea Aubl., partly because of its 5 cells. However, the regular branching with whorls of horizontal branches is suggestive of the latter. Matisia has been treated as a synonym by some authors.

Figure 3 by Antonio Dueñas V. from a fresh specimen shows the fleshy berry and stout peduncle before shrinkage in drying. This artist accompanied the forest survey for a month to make drawings for the tree book.

A number of species have been described in this genus from northwestern South America in recent years. Some of these seem to be of local distribution. Matisia coloradorum R. Benoist was described from Santo Domingo de los Colorados, in the adjacent Province of Pichincha. M. alata Little and M. grandifolia Little were based on the author's specimens of 1943. The 1965 collection contains incomple te material of 1 or 2 additional unnamed species. 
RUDOEA JATIVAR Little, sp. nov. Fig. 4.

Arbor mediocris at $19 \mathrm{~m}$. alta, trunco $30 \mathrm{~cm}$. diametro. Cortex asper fulvescens. Ramuli juventute puberuli, demum glabri, nodis annulatis saepe incrassatis. Folia opposita, stipulis truncatis $3 \mathrm{~mm}$. longis puberulis, setiferis, petiolis $1-2 \mathrm{~cm}$. longis, glabris, longitudinaliter sulcatis. Laminae ellipticae vel ovatae, 10-15 cm. longae, $4-7 \mathrm{~cm}$. latae, glabrae, coriaceae, apice acuminatae, basi acutae, supra virides nitidae nervis lateralibus utroque latere 7-11 curvis atque valde impressis ante marginem conjunctis, subtus pallidae impolitae nerviis laterales elevatis.

Inflorescentia terminalis paniculata $4-5 \mathrm{~cm}$. longa, pedunculo brevi 1-2 cm. longo, multos flores sessiles aggregatos in capitula ramis oppositis puberulis ferens. Flores in alabastro $7 \mathrm{~mm}$. longi; hypanthium $2 \mathrm{~mm}$. longum et latum, puberulum; calyx $1 \mathrm{~mm}$. longus, minute 5-dentatus margine ciliatus; corolla infundibuliformis extus puberula, tubo $4 \mathrm{~mm}$. longo, $3 \mathrm{~mm}$. lato, ad faucem dense albo-barbato, lobis 5 anguste oblongis $4-5 \mathrm{~mm}$. longis patentibus; stamina 5 , paulo exserta, ad apicem tubi corolla inserta, filamentis fere $1 \mathrm{~mm}$. longis, antheris anguste oblongis $1.5 \mathrm{~mm}$. longis; stylus $5-6 \mathrm{~mm}$. longus puberulus exsertus stigmatibus $1 \mathrm{~mm}$. longis. Fructus deest.

Medium-sized tree to $19 \mathrm{~m}$. high, with trunk $30 \mathrm{~cm}$. in diameter. Bark rough, yellow brown. Twigs puberulent when young, becoming glabrous, with ringed nodes often thickened. Leaves opposite, with truncate puberulous stipules bearing setae, with glabrous petioles 1-2 cm. long longitudinally grooved. Blades elliptic or ovate, 10-15 cm. long, 4-7 cm. wide, glabrous, coriaceous, acuminate at apex, acute at base, above shiny green with 7-11 lateral veins on each side, curved and deeply impressed, joined before margin, beneath pale and dull with lateral veins raised.

Inflorescence terminal, paniculate, $4-5 \mathrm{~cm}$. long, with short peduncle $1-2 \mathrm{~cm}$ 。long, bearing many sessile flowers clustered in heads on opposite puberulent branches. Flowers in bud $7 \mathrm{~mm}$. long; hypanthium $2 \mathrm{~mm}$. long and broad, puberulent; calyx $1 \mathrm{~mm}$. long, mirutely 5-toothed, ciliate on margin; corolla funnelshaped, puberulent on outside, with tube $4 \mathrm{~mm}$. long, $3 \mathrm{~mm}$. broad, densely white-bearded in throat, with 5 narrowly oblong spreading lobes $4-5 \mathrm{~mm}$; ; stamens 5 , slightly exserted, inserted at apex of corolla tube, with filaments nearly $1 \mathrm{~mm}$. long and narowly oblong anthers $1.5 \mathrm{~mm}$. long; style $5-6 \mathrm{~mm}$. long, puberulent, exserted, with stigmas $1 \mathrm{~mm}$. long. Fruit lacking.

The sapwood is whitish. 
ECUADOR, ESMERALDAS: Tobar Donoso Cerro, Junction of Río San Juan and Río Camumbi, alt. $260 \mathrm{~m}$., wet tropical forest, common, July 26, 1966, Carlos Játiva 328 (HOLOTYPE, US; isotypes, LA, NY). COLOMBIA: El Chocó, S. of Río Condoto, between Quebrada Guarapo and Mandinga, alt. 120-180 m., dense forest, Apr. 22-28, 1939, E. P. Killip 35426 (US).

This medium-sized tree from Esmeraldas has short-petioled elliptic or ovate glabrous shiny leaves with 7-11 curved and very impressed lateral veins on each side and numerous sessile flowers crowded in paniculate heads. Killip 35426 is referred to this new species. That small unicate specimen from a tall tree consists of a fallen twig with 2 leaves, also 2 detached leaves apparently different, and a detached globose glabrous white fruit $1.5 \mathrm{~cm}$. in diameter.

Carlos Játiva, Ecuadoran botanist, collected tree specimens for this project in Esmeraldas in 1966, including this type.

Rudgea Salisb. is a tropical American genus of more than 150 species. Earlier, Paul C. Standley (The Rubiaceae of Ecuador. Field Mus. Nat. Hist. Bot. Ser. 7: 179-251. 1931) recorded from Ecuador only 1 species, R. fimbriata (Benth.) Standl., a shrub of wide distribution from Central America to Brazil.

SICKINGIA STANDLEII Little, sp. nov. "Mang1111o," "colorado." Fig. 5 .

Arbor ad $25 \mathrm{~m}$. alta, trunco $30 \mathrm{~cm}$. diametro. Cortex interior succo rubro. Ramuli crassi, leviter quadrangulares nodis annulatis atque cicatricibus foliaribus magnis elongatis. Folia opposita stipulis caducis non visis, petiolo crasso $3-4 \mathrm{~cm}$. longo, leviter puberulo. Laminae suborbiculares vel late ellipticae, 20-28 cm. longae, $21 \mathrm{~cm}$. latae, subcoriaceae, apice rotundatae et mucronatae, basi subcordatae, nervis lateralibus utroque latere c. 15 sub angulo fere $90^{\circ}$ abeuntibus prope marginem conjunctis, supra glabrae et leviter nitidae, subtus pallidae nervis puberulis.

Inflorescentiae terminales paniculatae c. $6-9 \mathrm{~cm}$. Iongae ramulis puberulis. Flores multi $7 \mathrm{~mm}$. longi sessiles, bracteis late triangularibus ciliatis; hypanthium clavatum $3-4 \mathrm{~mm}$. longum puberulum; calyx breve tubulosus, $1 \mathrm{~mm}$. longus, puberulus ciliatus 5-dentatus; corolla in alabastro cylindrica tubo breve et lobis 5 versus apicem puberulis; stamina 5 prope basin tubi corollae inserta, filamentis $0.5 \mathrm{~mm}$. longis, anteris oblongis $2 \mathrm{~mm}$. longis; ovarium 2-loculare, ovulis numerosis in quoque loculo, stylus $2 \mathrm{~mm}$. Iongus 2-partitus. Capsula globosa $1.5 \mathrm{~cm}$. diametro, 2-loculare seminibus numerosis applanatis. 


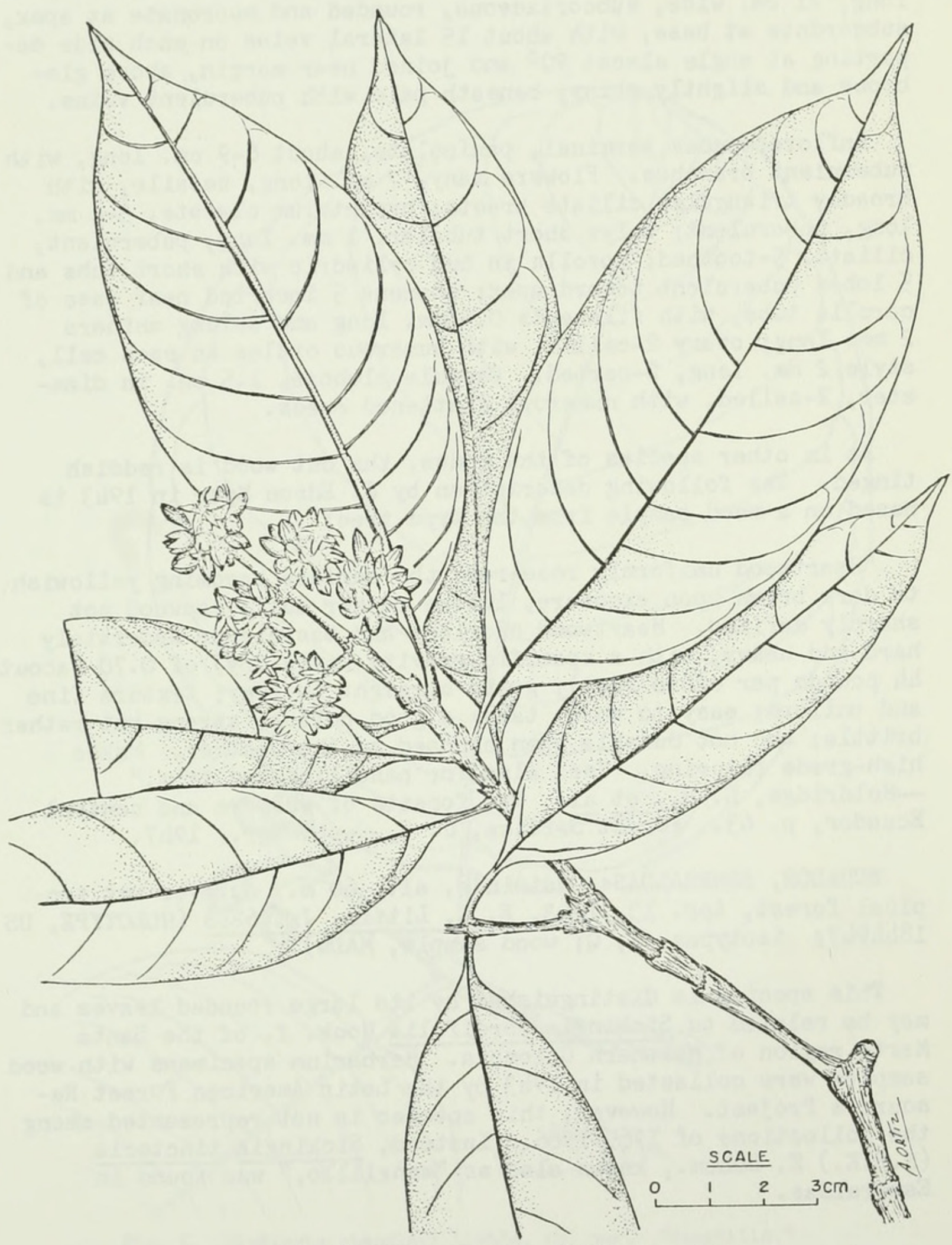

Fig. 4. Rudgea fativae Little, sp. nov. 
Tree to $25 \mathrm{~m}$. high, with trunk $30 \mathrm{~cm}$. in diameter. Inner bark with beet-red sap. Twigs stout, slightly l-angled, with ringed nodes and large elongate leaf scars. Leaves opposite with caducous stipules not seen, with stout, slightly puberulent petiole $3-4 \mathrm{~cm}$. long. Blades suborbicular or broadly elliptic, $20-28 \mathrm{~cm}$. long, $21 \mathrm{~cm}$. wide, subcoriaceous, rounded and mucronate at apex, subcordate at base, with about 15 lateral veins on each side departing at angle almost $90^{\circ}$ and joired near margin, above glabrous and slightly shiny, beneath pale with puberulent veins.

Inflorescences terminal, paniculate, about $6-9 \mathrm{~cm}$. Iong, with puberulent branches. Flowers many, $7 \mathrm{~mm}$. long, sessile, with broadly triangular ciliate bracts; hypanthium clavate, 3-4 mm. long, puberulent; calyx short tubular, $1 \mathrm{~mm}$. long, puberulent, ciliate, 5-toothed; corolla in bud cylindric with short tube and 5 lobes puberulent toward apex; stamens 5 inserted near base of corolla tube, with filaments $0.5 \mathrm{~mm}$. long and oblong anthers $2 \mathrm{~mm}$. long; ovary 2-celled, with numerous ovules in each cell, style $2 \mathrm{~mm}$. long, 2-parted. Capsule globose, $1.5 \mathrm{~cm}$. in diameter, 2-celled, with numerous flattened seeds.

As in other species of the genus, the cut wood is reddish tinged. The following description by J. Edson Myer in 1943 is based on a wood sample from the type tree:

"Heartwood uniformly rose-red, the surface becoming yellowish to dark brown upon exposure, lustre rather dull; sapwood not sharply defined. Heartwood odorless and tasteless; moderately hard and heavy, with a specific gravity (oven-dry) of 0.70 (about 44 pounds per cubic foot); grain straight to roey; texture fine and uniform; easy to work, takes a good polish; strong but rather brittle; and not durable when exposed to the weather. Makes high-grade flooring. Used also for panelling and trim." -Holdridge, L. R., et al. The forests of western and central Ecuador, p. 63. Forest Service, U. S. Dept. Agr. 1947.

ECUADOR, ESMERALDAS: Quinindé, alt. $60 \mathrm{~m}$., cutover wet tropical forest, Apr. 13, 1943, E. L. Little, Jr. 6248 (HOLOTYPE, US 1844947; isotypes, F, Q; wood sample, MADw).

This species is distinguished by its large rounded leaves and may be related to Sickingia cordifolia Hook. f. of the Santa Marta region of northern Colombia. Herbarium specimens with wood samples were collected in 1943 by the Latin American Forest Resources Project. However, this species is not represented among the collections of 1965-1966. Instead, Sickingia tinctoria (H.B.K.) K. Schum., known also as "manglillo," was found in Esmeraldas. 


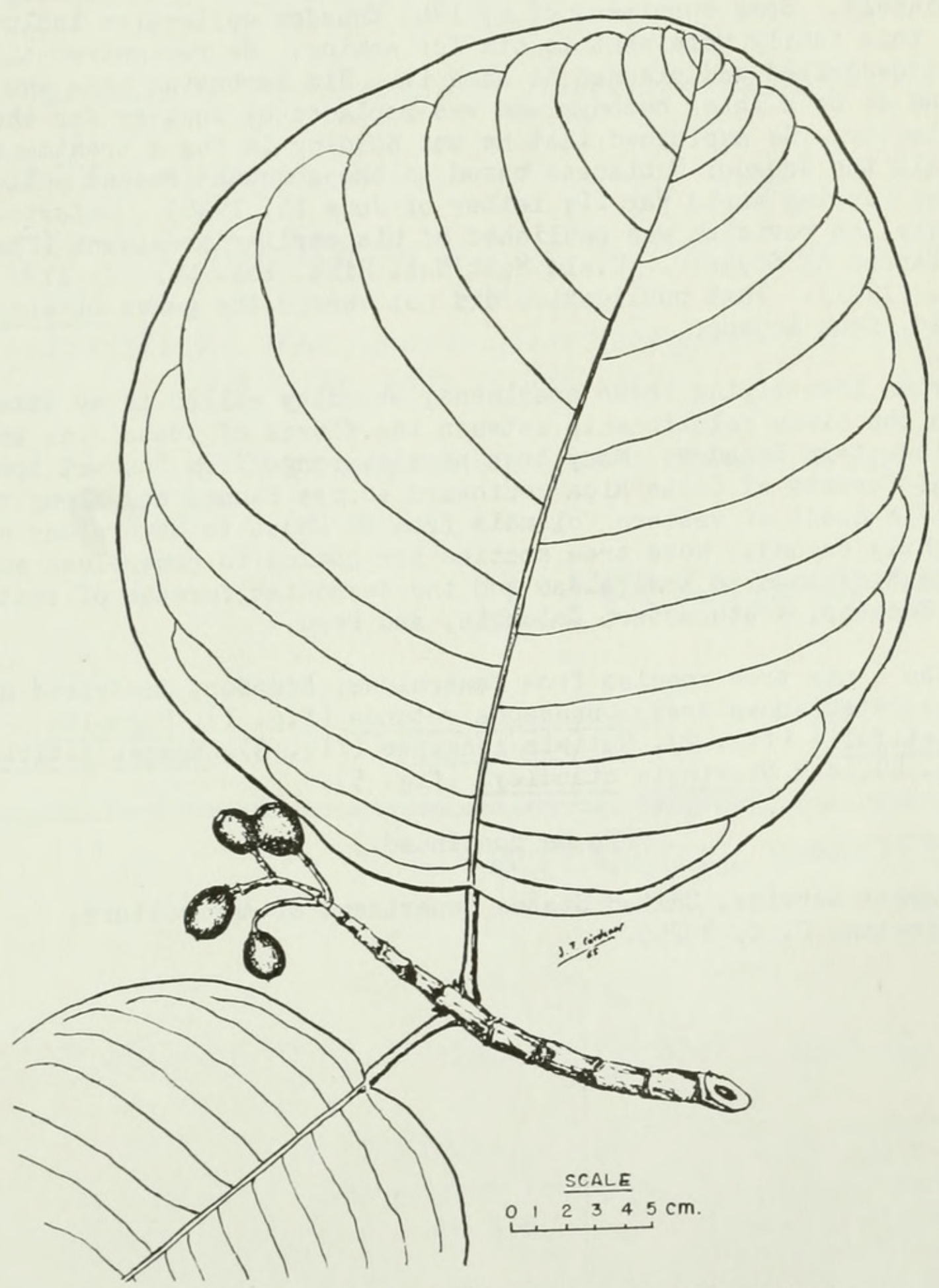

Fig. 5. Sickingia standleyi Little, sp. nov. "Manglillo." 
This tree was cited as Sickingia sp. nov. "Mangli1lo" in my published list of the 1943 collection ( $A$ collection of tree specimens from western Ecuador. Caríbbean Forester 9: 215-298. 1948; pp. 275, 281).

It is a pleasure to associate this species with Paul Carpenter Standley (1884-1964), outstanding authority on New World plants, author of numerous useful floras, and specialist on the family Rubiaceae. Some specimens of my 1943 Ecuador collection including this family were sent to him for naming. He recognized this as undescribed and planned to name it. His herbarium name was noted to be a later homonym and was replaced by anotizer for the collector. He explained that he was holding it for a treatment of all the Ecuador Rubiaceae based on the abundant recent collections (during World War II; letter of June 14, 1946). Unfortunately, no revision was published of his earlier treatment (The Rubiaceae of Ecuador. Field Mus. Nat. Hist. Bot. Ser. 7: 179251. 1931). That publication did not record the genus Sickingia Willd. from Ecuador.

When identifying these specimens, Standley called to my attention the close relationship between the floras of Costa Rica and northwestern Ecuador. Many tree species range from the wet tropical forests of Costa Rica southward across Panama and along the Pacific coast of western Colombia from El Chocó to Esmeraldas or slightly beyond. More tree species are common to Esmeraldas and Costa Rica than to Esmeraldas and the Amazonian forests of eastern Ecuador, southeastern Colombia, and Peru.

The 5 new tree species from Esmeraldas, Ecuador, described and illustrated above are: Coussapoa rotunda ( $\mathrm{fig}$. 1), Magnolia striatifolia (fig. 2), Matisia longipes (fig. 3), Rudgea jativae (fig. 4), and Sickingia standleyi (fig. 5).

(To be continued.)

Forest Service, United States Department of Agriculture, Washington, D. C. 20250. 


\section{$2 \mathrm{BHL}$ Biodiversity Heritage Library}

Little, Elbert L. 1969. "New tree species from Esmeraldas, Ecuador." Phytologia 18, 195-208. https://doi.org/10.5962/bhl.part.28886.

View This Item Online: https://www.biodiversitylibrary.org/item/46719

DOI: https://doi.org/10.5962/bhl.part.28886

Permalink: https://www.biodiversitylibrary.org/partpdf/28886

\section{Holding Institution}

New York Botanical Garden, LuEsther T. Mertz Library

\section{Sponsored by}

The LuEsther T Mertz Library, the New York Botanical Garden

\section{Copyright \& Reuse}

Copyright Status: In copyright. Digitized with the permission of the rights holder.

Rights Holder: Phytologia

License: http://creativecommons.org/licenses/by-nc-sa/3.0/

Rights: https://biodiversitylibrary.org/permissions

This document was created from content at the Biodiversity Heritage Library, the world's largest open access digital library for biodiversity literature and archives. Visit BHL at https://www.biodiversitylibrary.org. 